<綜 説 >

(受理 : 平成 15 年 8 月 19 日)

\title{
増粘剂・レオロジー改質剤の技術動向 Trend of Thickeners or Rheology Modifiers
}

\author{
松田 光夫 ${ }^{*}$ \\ Mitsuo MATSUDA
}

\section{1.はじめに}

系の粘度を高める目的で添加される増粘剤は, 塗料や 食品・化粧品・繊維の捺染など衣食住の様々な分野で広 く利用されている。多孔質材用の接着剤には塗布したと きによく広がりすぐには染み込まない適度の粘り気があ るし, 家庭用塗料には濡れや刷毛さばきに優れ，へこみ・ ムラ・たれのない性能が要求される。身近な食品でも卜 マトピューレとガムシロップとでは, その物性・流動性 が全く異なる。このように一口に高い粘度といっても， 增粘剂に期待される物性は一様ではないし，その機能を 粘度という尺度だけで表現することもできそうにない。

レオロジー（Rhelogy）は物質の変形と流動を扱う科 学として 20 世紀前半に成立し発展した。フックの弾性 の法則とニュートンの粘性の法則とを二つの柱とするこ の比較的新しい学問分野が, 流体の特性を説明するため に大きな役割を果たしているリ。レオロジーの名は古代 ギリシャの哲学者へラクレイトスの言葉 “万物は流転す る”（Penta rhei）に因んで名付けられた。粘性と弾性 という相異なる概念を止揚して新たな領域を切り開いた レオロジーは，まさにへラクレイトスの弁証法の思想を 具現化したあのと言えそうである。

流体に対してそれぞれの用途に合った物性を付与する ために用いる添加剤は, 単に增粘剤というょり, あっと 栍極的な意味でレオロジー改質剤という方が本当は相応 しいのだろう。本稿では, 最近進展が著しい会合性増粘 剤の話題を中心に，主にコーティング剤の分野で展開さ れている增粘剤あるいはレオロジー改質剤の概要と技術 動向を紹介したい。

*ローディア日華 (蛜応用開発研究部

福井県福井市文京 4 丁目 23-1 $\overline{\text { T 910-8670 }}$

R\&D Application Laboratory Rhodia Nicca Ltd.

4-23-1 Bunkyo, Fukui-shi, Fukui 910-8670, Japan

\section{2. 流動と粘弾性}

流動に関する現象を理解するためにまず流体のモデル を図 1 に示した。

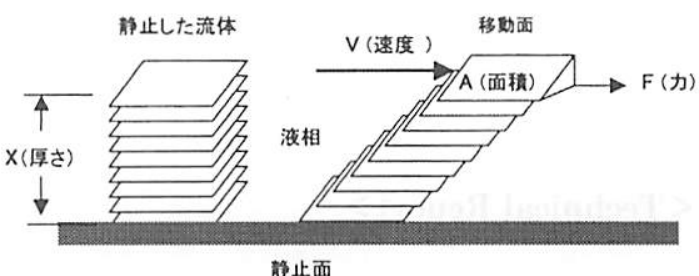

図 1 流体のモデル

二つの平行な平面間に存在する流体を考え，任意の平 面上で流動方向に加わる力 $\mathrm{F}$ を移動面の面積 $\mathrm{A}$ で割っ たものをずり応力 $\tau$ とする。变形の速度 $\mathrm{V}$ を移動面と 静止面間の距離 X で割ったものをずり速度 $\gamma$ とすると, 粘度 $\eta$ はずり応力とずり速度の比， $\tau / \gamma$ で表わされる。

$$
\begin{aligned}
& \tau=\mathrm{F} / \mathrm{A} \quad\left(\text { dyne } / \mathrm{cm}^{2}\right) \\
& \gamma=\mathrm{V} / \mathrm{X} \quad\left(\mathrm{sec}^{-1}\right) \\
& \eta=\tau / \gamma \quad \text { (dyne } \cdot \mathrm{sec} / \mathrm{cm}^{2} \text { ) }
\end{aligned}
$$

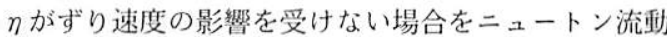

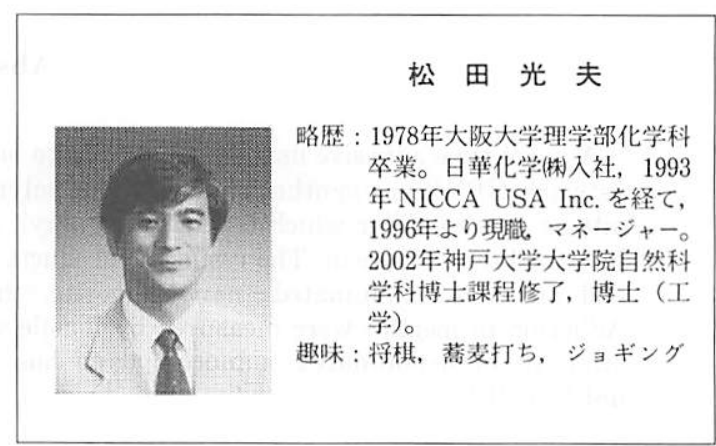



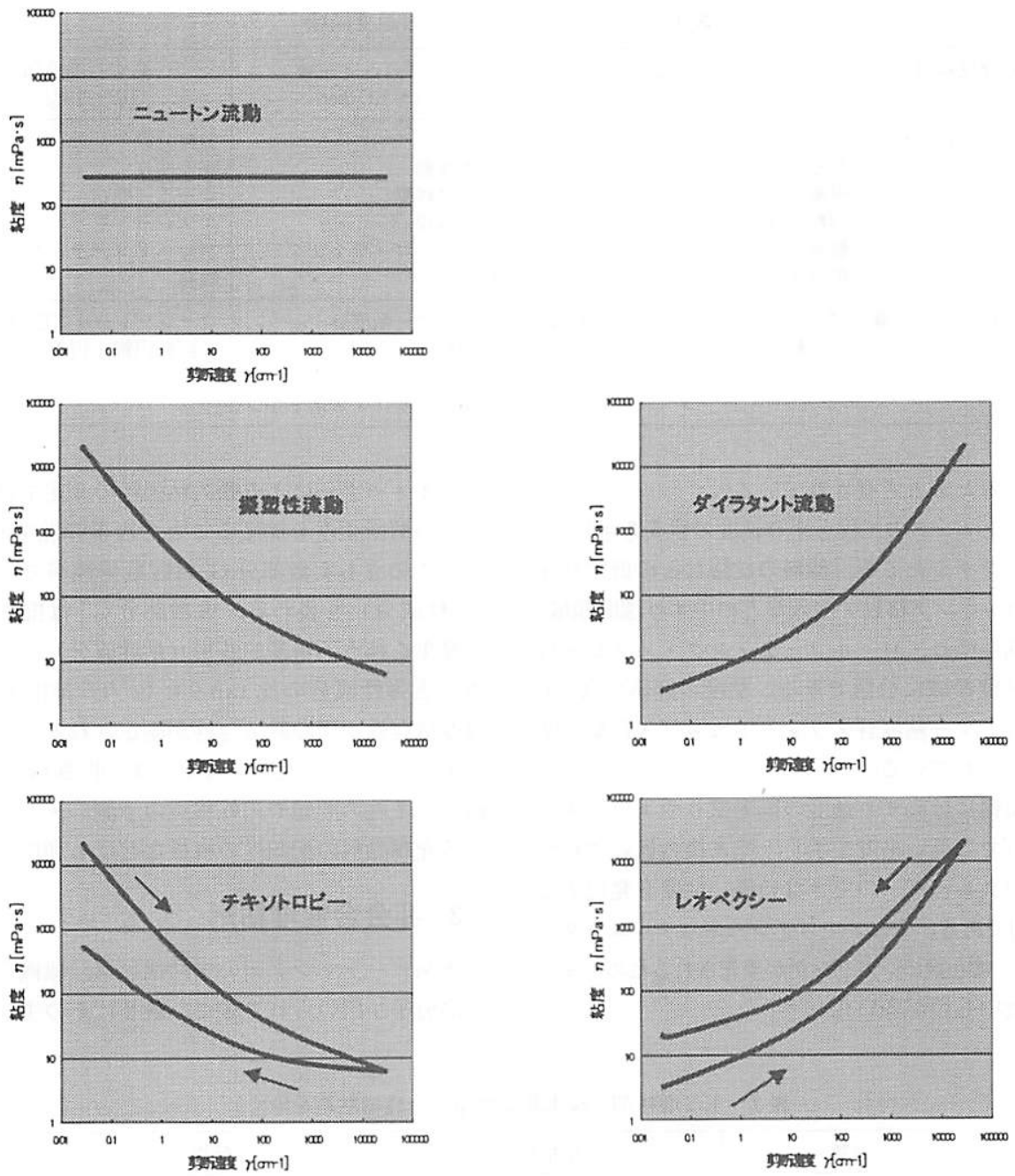

図 2 粘度とずり速度の関係

という。水や有機溶媒あるいは分子レベルで溶解した低 分子化合物の真溶液などはいずれもニュートン流体であ る。けれども高分子で增粘した系やコロイド分散液など の系ではしばしば非ニュートン的な流動現象がみられる。 図 2 にずり速度と粘度との関係から種々の流動性を示し た。

ずり速度が大きくなるにつれて粘度が減少する場合を 擬塑性（pseudoplastic）流動という。放置しておくと 流動せず固体のような弾性を示すが, ある一定の力（降 伏值）を越えると流動する場合を塑性流動（plastic flow） いう。特にその流動が直線的なニュートン流動のものを ビンガム流動之呼んでいる。ビンガムは米国の物理学者 でレオロジーの提唱者であある。擬塑性と逆でずり速度 が大きくなるにつれて粘度が増大する場合をダイラタン シー（dilatancy）という。一方，剪断（ずり）によっ て変化した構造の回復に時間がかかる場合は, ずり速度 の上昇時と下降時に異なった粘度曲線となる。こうした 粘度の時間依存性を持つものには, ずり速度の增加につ れて粘度が隇少するチキントロピー（thixotropy）と， 逆に增大するレオペクシー（rheopexy）がある。一般 に，かき混ぜるとソル状になり，静置するとゲル状にな る可逆的な性質をチキントロピーと呼ぶことも多い2)。

ガムシロップはニュートン流動, トマトピューレは塑 性流動に分類できる。蜂蜜の場合は種類で異なり, クロー バー蜂蜜はニュートン流動，ヒース蜂蜜はチキソトロピー, ユーカリ蜂蜜ばダイラタンシーを示すという。ヒース蜂 蜜は $2 \%$ 含まれるタンパク質が 3 次元の網目構造を形成 し，ユーカリ蜂蜜は $5 \%$ 含まれるデキストランが固い粒 
表 1 コーティング工程のずり速度領域

\begin{tabular}{|c|c|c|c|}
\hline ずり速度領域 & $\begin{array}{c}\text { 低ずり速度領域 } \\
10^{-3} \sim 1 / \mathrm{sec}\end{array}$ & $\begin{array}{c}\text { 中ずり速度領域 } \\
1 \sim 10^{3} / \mathrm{sec}\end{array}$ & $\begin{array}{c}\text { 高ずり速度領域 } \\
10^{3} \sim 10^{6} / \mathrm{sec}\end{array}$ \\
\hline $\begin{array}{c}\text { コーティングに関わる } \\
\text { 工程 }\end{array}$ & $\begin{array}{l}\text { レベリング } \\
\text { たるみ } \\
\text { 憵濁 } \\
\text { 顔料の沈降 } \\
\text { 離液 } \\
\text { 色浮き }\end{array}$ & $\begin{array}{l}\text { 混合 } \\
\text { 注ぎ移動 } \\
\text { ポンブ移動 } \\
\text { 刷毛含浸 } \\
\text { カーテンンーティング } \\
\text { 軟度 }\end{array}$ & 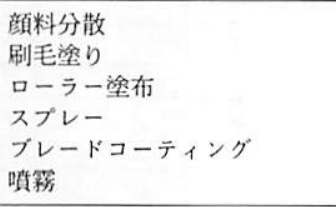 \\
\hline 対応する粘度測定装置 & $\begin{array}{l}\text { ブルックフィールト (B) 型粘度計 } \\
<\text { 回転円板型 }>\end{array}$ & $\begin{array}{l}\text { ストーマー粘度計 } \\
\text { <回䎐パドル型 }> \\
\text { フォードカップ } \\
\text { <単孔オリフィス落下型 }>\end{array}$ & $\begin{array}{l}\text { コーンプレート (E) 型粘度計 } \\
\text { <回転円錐一円板型 > }\end{array}$ \\
\hline
\end{tabular}

状になっているためと考察されている3)。

表 1 にコーティングの工程とずり速度の目安を示した。 塗料のレベリングやたるみ, 顔料の沈降などの低ずり速 度領域, 混合・ポンプ移動・注入などの中ずり速度領域, 顔料分散・刷毛塗り・ロールコーティング・スプレーな どの高ずり速度領域に分類できる。粘度の評価には, B 型粘度計・ストマー粘度計・フォードカップ・ $\mathrm{E}$ 型粘度 計などが用いられている。

建築物用塗料には高ずり速度の刷毛塗りやエアレスス プレー条件下では低い粘度を示し, 染布後の低いずり速 度ではたれやクレーターのできない高い粘度を発現する あのが一般的である。またエアスプレーやロールコーター 用の塗料では, 塗布後のレベリングが優先されるためニュー トン流動に近いものが多い4)。
レオメーターによる動的粘弾性の測定では, 試料に正 弦波の剪断丕みを加えることで複素弾性率 $\mathrm{G}^{*}$ が得られ る。このうち実数部分 $\mathrm{G}^{\prime}$ は眝蔵弾性率で可逆的な変形 （弾性成分）を表わし, 虚数部分 $\mathrm{G}^{\prime \prime}$ は損失弾性率で熱 の発生を伴う不可逆的変形（粘性成分）を表わす。粘性 成分之弹性成分の比 $\tan \theta=\mathrm{G}^{\prime \prime} / \mathrm{G}^{\prime}$ は損失正接でその 温度依存性や周波数依存性が測定される。レオメーター を用いた粘弾性測定は, 塗装作業の問題解決にも有効で, 耐八ジキ性の問題や相転移点の予測, メタリック感を与 える光輝顔料の配向性の解析などにむ利用されている5゙。

\section{3. 非会合性増粘剤}

水系コーティング用の增粘剤には, 無機化合物や水溶 性高分子が用いられてきた。表 2 にその主なものを示し

表 2 主な增粘剤（疎水基変性型会合性增粘剤を除く）

\begin{tabular}{|c|c|c|}
\hline 分類 & 增粘戍 & 特徽 \\
\hline 無機化合物 & $\begin{array}{l}\text { ベントナイト } \\
\text { モンモリロナイト } \\
\text { シリカ }\end{array}$ & 擬塑性, 降伏值 \\
\hline セルロース系 & 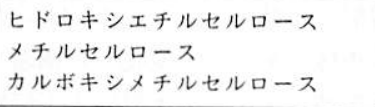 & $\begin{array}{l}\text { 擬塑性 } \\
\text { 擬塑性 } \\
\text { チキソトロピー }\end{array}$ \\
\hline 天然物 & $\begin{array}{l}\text { キサンタンガム } \\
\text { サクシノグルカン } \\
\text { アルギン酸ソータ } \\
\text { グアガム } \\
\text { カラギーナン } \\
\text { カゼイン }\end{array}$ & $\begin{array}{l}\text { 高い撴塑性, 降伏值 } \\
\text { 極めて高い擬塑性 } \\
\text { 擬塑性（ニュートン流䡃に近い） } \\
\text { 擬塑性 } \\
\text { ゲル形成 }\end{array}$ \\
\hline 合成非イオン系ポリマー & $\begin{array}{l}\text { ポリビニルアルコール } \\
\text { ポリエチレンオキサイト } \\
\text { ポリピニルピロリドン } \\
\text { ポリアクリルアミト }\end{array}$ & $\begin{array}{l}\text { ニュートン流理 } \\
\text { チキソトロピー, 降伏值 } \\
\text { 擬盟性 }\end{array}$ \\
\hline 合成アニオン系ポリマー & $\begin{array}{l}\text { ポリアクリル酸およひぞの塩 } \\
\text { アルカリ可溶型ポリアクリレート }\end{array}$ & $\begin{array}{l}\text { ニュートン流理 } \\
\text { 掓塑性, } \mathrm{pH} \text { 依存性 }\end{array}$ \\
\hline 界面活性派 & $\begin{array}{l}\text { アミンオキサイド } \\
\text { アルカノールアミト }\end{array}$ & $\begin{array}{l}\text { 耐酸性, 耐塩性 } \\
\text { 電解質との相乗効果大 }\end{array}$ \\
\hline
\end{tabular}



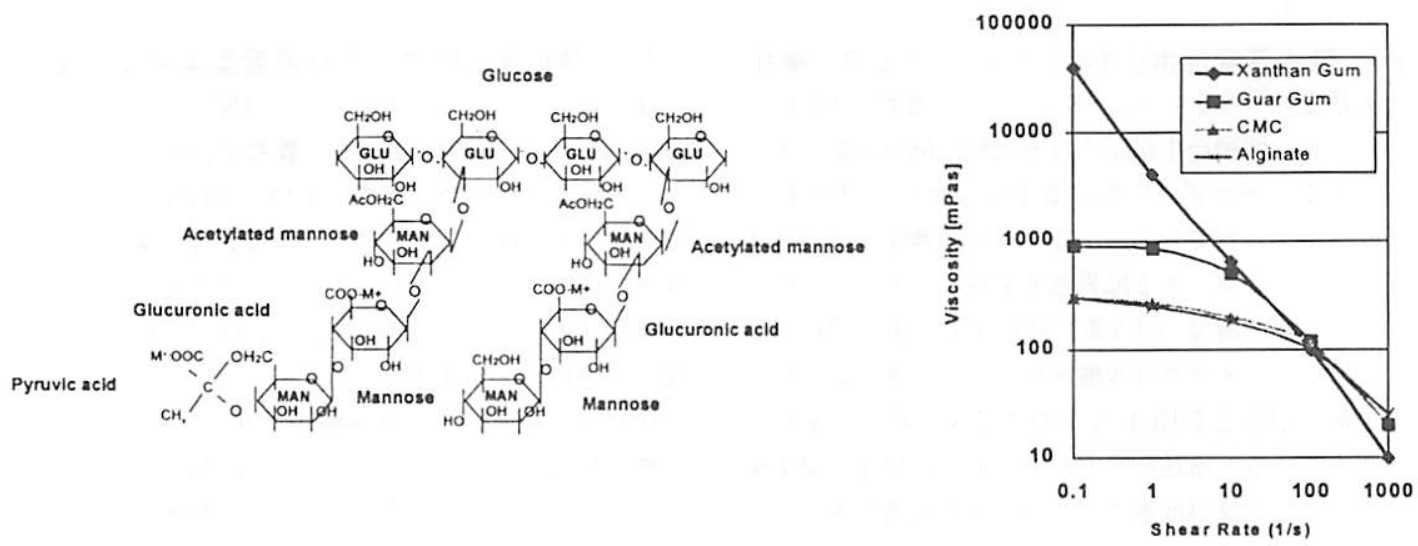

図 3 キサンタンガムの構造と主な天然物增粘剤のずり速度と粘度の関係

た ${ }^{6)}$

天然クレー系は降伏值を持ち塑性流動を示するのが多 い。膨潤した層状結晶があたかもトランプカードで組み 立てた家のように縦横に絡みあうカード八ウス効果で構 造粘性を発現する。変性セルロース系は㯰換基の種類と 置換度により特徴ある举動を示す。その置換度が高くな るにつれて, カルボキシメチルセルロースは強いチキソ トロピー性を示し，ヒドロキシエチルセルロースは擬塑 性流動を示す。天然の多糖類が增粘剤として使われるこ と屯多い。キサンタンガムは, 好気性発醉で得られる分 子量約 200 万のアニオン性多糖類で顕著な擬塑性流動を 示す。（図 3）このため分散物の沈降防止剤として特に 有用である。こうした微生物の産生する多糖類は最近注 目されており，更に高分子量（約 600 万）のサクシノグ ルカン（レオザン）やメチルフィルス属の産生物などが 化粧品やセメント混和剂のレオロジーの改質に応用され ている ${ }^{7.8)}$ 。ヒドロキシプロピル化グアガムは，低級 アルコールの増粘にも有用で消臭剤ゲルに応用されてい る9)。カラギーナンは, 紅藻類の海草から抽出される直 鎖状の多糖類で糖単位に結合した硫酸基の数と位置によ り $\kappa, \iota, \lambda の 3$ 種がある。コイル状からダブルヘリック スの構造を取りゲル化すると言われているがその詳細は まだ十分明らかになってはいない。コンピュータシュミ レーションを用いた分子動力学的な構造解析が武みられ ている ${ }^{10)}$

合成非イオン系の增粘剤は，いかなるイオン性を持つ 化合物之む相溶性が良好で, 耐塩性に優れるという特徵 がある。その流動性はニュートン流動に近い。一方，了 ルカリ可溶型のアクリルエマルション（Alkali-Soluble Emulsion, ASE) はカルポキシル基を多く含むポリマー でアアルカリ中和によって生じるアニオン同士の反発に より可溶化して水中で広がり網目構造を形成して增粘す
る。このため擬塑性流動を示す。界面活性剤は, 球状 棒状・ラメラ状のミセルを形成することで增粘する。シャ ンプーや洗浄剂用途に広く応用されている。

\section{4. 会合性增粘剂}

水溶性高分子の分子鎖の絡まりや膨潤などの流体力学 的なサイズ効果と擬集によって增粘する従来型の增粘剤 に対して，疎水基を有する水溶性高分子で疎水基間の会 合によって増粘するものは会合性増粘剤（Associative thickener）と呼ばれている。疎水基としては通常，炭 素数 12〜22 のアルキル基等が用いられている。疎水基 が親水性のポリマー主鎖の末端にあるもの，ブロックポ リマーとして繰返しの疎水性セグメント部位を構成して いるもの，親水性の主鎖にペンダント状に疎水基を共重 合したすのなどがある。図 4 に代表的な会合性增粘剤の

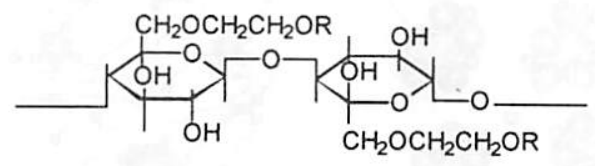

Hydrophobe modified hydroxyethylcellulose (HMHEC)<smiles>CCOC(=O)NNC(=O)CCCOC(=O)NNC(=O)OCC</smiles>

Hydrophobe modified ethoxylatedurethane(HEUR)<smiles>CCC(CC)CCCC(CC)C(=O)O[Na]</smiles>

Hydrophobe modified alkalisoluble emulsion (HASE)

図 4 会合性增粘剤の例 
構造を示した。

\section{1 疎水基変性ポリオキシエチレンウレタン樹脂}

疎水基変性ポリオキシエチレンウレタン樹脂（HEUR） は，非イオン性縮合主鎖からなる比較的低分子量のポリ マーである。ゼロずり粘度の濃度依存性から HEUR の 会合性が調へられている11)。低い增粘剤濃度では会合体 は孤立しているが, ある臨界濃度を越えるとミセル間の ブリッジが生じ濃度の 3.5 乗に比例する急激な增粘が観 察された。ポリメタクリル酸メチルやポリスチレン粒子 の水分散型樹脂と HEUR が共存する系の粘弾性挙動む 測定されている。増粘剂濃度が低い系では粒子の凝集構 造体を形成し沈降が促進されるが，適切な濃度まで上げ ると非会合性增粘剤でみられるような粒子凝集は起らず 安定な分散状態になる。

このように会合性增粘剤はその疎水基同士が会合して 擬似架橋構造のネットワークを形成するだけでなく，塗 料中の顔料やバインダー粒子の表面にも吸着するのが大 きな特徵である。その結果として, 光沢と発色性に優れ

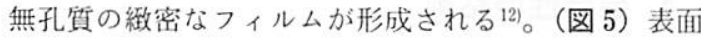
修飾された酸化チタンの粒子と共存する系で, 表面の分 散剤が後源加した HEUR の疎水基の吸着によって置き 換わる現象も確認されている ${ }^{13)}$
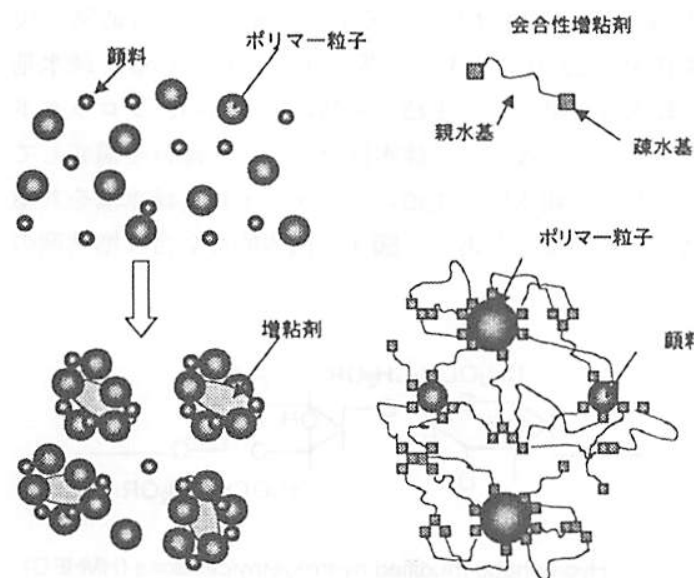

図 5 非会合性增粘剂による凝集現象之会合性增粘剤 の吸着

ASE を除くほとんどの非会合性增粘剤は粉末状で水 に溶解して使用するか，この操作は実際にはかなり煩雑 である。HEUR は扱いやすい液状品であるが,ポリマー 濃度が高い增粘剤自身の性状はできるだけ低粘度である ことが望ましい。最近では VOC 規制への対応から，従 来のアルコール溶剤等に代えて, アルキルポリグリコシ ド ${ }^{14) や シ ク ロ テ ゙ キ ス ト リ ン ~}{ }^{15)}$ を用いる技術が開発され
ている。

\section{2 疎水基変性アルカリ可溶型エマルション}

蹯水基変性アルカリ可溶（または膨潤）エマルション （HASE）は，不飽和カルボン酸共重合体にマクロモ， マーの疎水基が担持した構造を持つ中程度ないし高分子 量のアニオン性ポリアクリレートである。製品の酸性条 件下（pH 2〜5）ではエマルションであるが，アルカリ で中和する（pH 7〜10）ことにより可溶化あるいは膨 潤して增粘性を発揮する。

HASE は例えばアクリル酸エチル（EA）とメタクリ ル酸（MAA），会合性モノマー（A-M）を乳化共重合 することより容易に合成できる。会合性モノマーとして は，アルコキシポリエチレングリコールメタクリレート やノニルフェノキシポリエチレングリコールメタクリレー ト16)，トリスチリルフェノキシポリエチレングリコール メタクリレート17)等が用いられる。

会合性モノマーの疎水基が小さい場合は二ュートン流 動に近い挙動を示すが, 大きくなると擬塑性流動を示す ようになり，增粘性む大きくなる。ポリマーの分子量む 物性に影響し，低分子量では高分子界面活性剤の性質を 示すが, 高分子量になるにつれて, レオロジー改質剤か ら增粘剤の性格が強くなる。

ドデシロキシポリエチレングリコール $(25 \mathrm{~mol}) \times タ$ クリレートと 2-アクリルアミド-2-メチルプロパンス ルホン酸ナトリウムのランダム共重合体の刺激応答性挙 動について, $\mathrm{C}_{12} \mathrm{E}_{25}$ 残基の会合によるポリマー鎖間の 相互作用とポリマー濃度・電解質濃度・ずり速度との関 係が研究されている ${ }^{18)}$ 。分子間の会合数が変わることに よって, 定常ずり粘度はずり速度が低領域・中領域・高 領域と高くなるに従い, ニュートン流動からダイラタン シーを経て擬塑性へと変化する。

疎水基部がもっとバルキーなベへニロキシポリエチレ ングリコール $(25 \mathrm{~mol})$ メタクリレート, トリスチリル フェノキシポリエチレングリコール $(25 \mathrm{~mol})$ メタクリ レートが会合性モノマーとして市販されている。（図 6)

$\mathrm{EA} / \mathrm{MAA} / \mathrm{A}$ - T の wt\%が 56/40/4のモノマー組成 で合成された会合性増粘剤（以下AT）を用いてスチレ ンーアクリル采のセミグロスペイントを調製し, 粘度の ずり速度依存性と動的粘弾性を測定した。長鎖アルキル の疎水基を持つ $\mathrm{BEM}$ の AT は, 多環型疎水基の SEM -25のATより屯擬塑性の傾向が強く, 低ずり速度で高 い粘度を示した。直鎖構造の方が低ずり条件下でより多 くの会合点を生成しやすいためと考えられる。一方, 中程度以上のずり速度では，逆に SEM-25の AT の 方が高い粘度を与える。BEM の方が会合点の笨離が起 りやすいためと考えられる。BEM の AT は損失正接 
<smiles>C=C(C)C(=O)OC(C)(C)CCOC(C)(C)CC</smiles>

SIPOMER BEM (Rhodia)

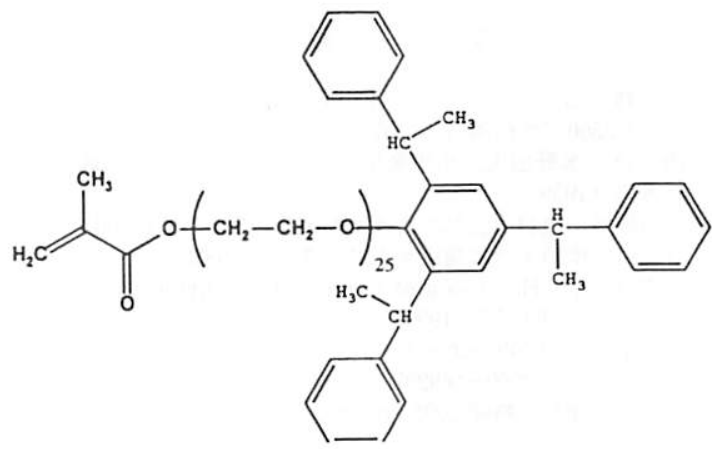

SIPOMER SEM-25 (Rhodia)

図 6 会合性モノマーの構造

$\tan \theta<1\left(G^{\prime}>G^{\prime \prime}\right)$ でより弾性成分が高く, SEM-25 の AT は逆に $\tan \theta>1$ でより粘性成分が高い。AT の 設計から適切な疎水基を選択することによって，レオロ ジー設計の幅を広げることが可能になることが期待でき る19)。

\section{3 その他の会合性増粘剤}

ウレタン系 (HEUR) とアクリル系 (HASE) 以外に も, 疎水基变性夕イプの增粘珴・レオロジー改質剤は広 く実用化されている。セルロース系は電解質や $\mathrm{pH}$ に対 する安定性を保持しながらより増粘性を高めている。ウ レタン系とアクリル系の混成型も登場している。その例 をいくつか挙げておく

HEET : 疎水基変性ポリオキシエチレンエーテル

HMHEC : 疎水基変性ヒドロキシエチルセルロース

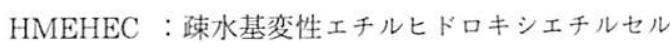
ロース

HEURASE : 疎水基変性ポリオキシエチレンウレタン アルカリ膨潤型エマルション

表 3 には, HEC と 3 種の会合性增粘剤の特徴をまと
めた。

\section{5.おわりに}

增粘剂・レオロジー改質剂について, 基礎的な事柄む 交えて最近の話題を中心に概説した。会合性増粘剤は, 1980 年代から市場に登場したが, 近年の VOC 削隇等 の器境問題に呼応した水系塗料の再評価に伴い, 改めて 脚光を浴びている。塗膜適性の調整は長年の経験と勘に 頼った絶妙の奥義であったが, コーティング成分間の相 互作用や流体の粘弾性挙動を解析することで, 科学的な アプローチが取り入れられつつある。從来, 応用の分野 においては, 粘度と TI 值（チキソトロピックインデク ス）だけで記述してきた增粘の世界が, 分子論的なレオ ロジーの改質の世界へ進化したとも言えるだろう。こう した高度のレオロジー特性の構築に, 分子設計の可能な 会合性増粘剤の技術開発が果たす役割は益々広がってゆ くものと思われる。

表 3 主な增粘剤の特徵

\begin{tabular}{|c|c|c|c|c|}
\hline & $\begin{array}{c}\text { ヒドロキシエチル } \\
\text { セルロース } \\
(\mathrm{HEC})\end{array}$ & $\begin{array}{c}\text { 疎水基変性ヒト゚ロキシ } \\
\text { エチルセルロース } \\
\text { (HMHEC) }\end{array}$ & $\begin{array}{c}\text { 柾水基変性アルカリ可溶 } \\
\text { 型エマルション } \\
\text { (HASE) }\end{array}$ & $\begin{array}{c}\text { 疎水基変性ポリオキシエチ } \\
\text { レンウレタン樹脂 } \\
\text { (HEUR) }\end{array}$ \\
\hline 長所 & $\begin{array}{l}\text { 顏料混和性 } \\
\text { 貯藏女安定性 } \\
\text { たるみ防止 } \\
\text { 耐水性 }\end{array}$ & $\begin{array}{l}\text { 八ネ防止: } \\
\text { 庥食防止 }\end{array}$ & $\begin{array}{l}\text { 高光沢 } \\
\text { レオロジーの多㥞性 } \\
\text { 経済性 } \\
\text { 扱いやすさ（低粘度） } \\
\text { 耐污染性 }\end{array}$ & 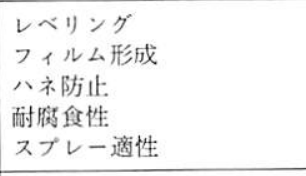 \\
\hline 短所 & $\begin{array}{l}\text { レベリング } \\
\text { フィルム形成 } \\
\text { 八ネ } \\
\text { 光沢 } \\
\text { 取扱いにくさ (粉体) }\end{array}$ & $\begin{array}{l}\text { 取扱いにくさ（粉体） } \\
\text { 的敗性 }\end{array}$ & $\begin{array}{l}\text { アルカリ中和の必要性 } \\
\text { 耐アルカリ性 } \\
\text { 初期の耐水性 }\end{array}$ & $\begin{array}{l}\text { 顔料による粘度低下 } \\
\text { 希釈による粘度低下 } \\
\text { 製品の高粘度 } \\
\text { 謇り・表面移行 } \\
\text { たるみ }\end{array}$ \\
\hline
\end{tabular}




\section{文献}

1）中川鶴太郎“レオロジー”第 2 版，岩波全書（1978）

2）JIS K5500 “隹料用語”（1977）

3）磯㨁道, 水野治夫, 小川廣男, “食品のレオロジー”成山 堂亘店 (1998)

4）上田隆宣，色材協会関西支部治料講座，33，113（2000）

5）谷口仁，法料・染装講座テキスト 3, 35（2001）

6) A. Farooq, "Handbook of Detergents", Surfactant Science Series, 82, 757 (1999)

7) 资生堂, 特開 2003-95881

8）東ソー, 特開 2000-169207

9）エステー化学, 特開 2002-209988
10）上田一義, 高分子加工, 52, 271（2003）

11）堀米操, 日本レオロジー学会誌, 29, 175 (2001)

12) P. Kalenda, Pigment \& Resin Technology, 31, 284 (2002)

13) M-R Tarng, M. Chen, J. E. Glass and J. G. Dickinson, Journal of Coatings Technology, 74, 45 (2002)

14） ヘンケル, 特表 2000-503056

15）ロース\&ハース, 特許第 3055816 (2000)

16) The Dow Chemical Company, USP 4, 384, 096 (1983)

17) Rhodia, USP $5,770,760$ (1998)

18）橋爪章仁, 森血洋太郎, 高分子, 51, 232 (2002)

19) D. Rita, C. Picuti, RHODIA Technical Report (2002)

20) G. D. Shay, The Dow Chemical Company, Technical seminar, (2003) 